\title{
PENERAPAN LOCATION BASED SERVICE UNTUK PENCARIAN LOKASI RAPAT MENGGUNAKAN METODE DESIGN SPRINT
}

\author{
Hirarki Ardi Pratama W, Joseph Dedy Irawan, Ahmad Faisol \\ Program Studi Teknik Informatika S1, Fakultas Teknologi Industri \\ Institut Teknologi Nasional Malang, Jalan Raya Karanglo km 2 Malang, Indonesia \\ 1618043@scholar.itn.ac.id
}

\begin{abstract}
ABSTRAK
Institut Teknologi Nasional Malang membuat aplikasi Sistem Informasi dan Manajemen Rapat berbasis android dan web, dimana aplikasi ini dapat membuat, mengatur, dan melihat jadwal rapat yang dilakukan oleh staff baik dosen ataupun karyawan ITN Malang. Akan tetapi masalah yang muncul pada aplikasi Sistem Informasi dan Manajemen Rapat ini adalah belum adanya fitur untuk mencari lokasi rapat. Masalah ini akan terjadi ketika rapat dilaksanakan diluar lingkungan ITN Malang terutama pada dosen atau karyawan baru yang belum mengetahui tentang lingkungan ITN Malang. Sehingga menyebabkan dosen atau karyawan terlambat dalam menghadiri rapat dikarenakan harus mencari lokasi rapat terlebih dahulu.

Berdasarkan latar belakang permasalahan tersebut peneliti ingin berkontribusi mengembangkan sistem dengan menambahkan fitur pencarian lokasi rapat memanfaatkan teknologi Location Based Service yang ada pada sistem operasi android dengan metode design sprint dalam mengembangkan Sistem Informasi dan Manajemen Rapat ITN Malang.

Hasil pengujian usability study kepada 7 orang dosen dan 2 orang karyawan Teknik Informatika ITN Malang menghasilkan kesimpulan bahwa pengembangan dari aplikasi SEMAR dengan menambahkan fitur pencarian lokasi rapat cukup membantu sebagian besar pengguna, sehingga tahap implementasi kepada programmer dapat dilakukan.
\end{abstract}

Kata Kunci : Location Based Services, Design Sprint, Sistem Informasi, Android

\section{PENDAHULUAN}

\subsection{Latar Belakang}

Institut Teknologi Nasional Malang membuat aplikasi Sistem Informasi dan Manajemen Rapat berbasis android dan web, dimana aplikasi ini dapat membuat, mengatur, dan melihat jadwal rapat yang dilakukan oleh staff baik dosen ataupun karyawan ITN Malang. Sistem ini juga dilengkapi fitur seperti melihat dan mengubah notulen pada suatu rapat, dan dapat menunggah atau mengunduh berkas pada suatu rapat berupa berkas foto dan dokumen.

Akan tetapi masalah yang muncul pada aplikasi Sistem Informasi dan Manajemen Rapat ini adalah belum adanya fitur untuk mencari lokasi rapat. Masalah ini akan terjadi ketika rapat dilaksanakan diluar lingkungan ITN Malang terutama pada dosen atau karyawan baru yang belum mengetahui tentang lingkungan ITN Malang. Sehingga menyebabkan dosen atau karyawan terlambat dalam menghadiri rapat dikarenakan harus mencari lokasi rapat terlebih dahulu. Berdasarkan latar belakang permasalahan tersebut peneliti ingin berkontribusi mengembangkan sistem dengan menambahkan fitur pencarian lokasi rapat memanfaatkan teknologi Location Based Service yang ada pada sistem operasi android dengan metode design sprint dalam mengembangkan Sistem Informasi dan Manajemen Rapat ITN Malang.

Design sprint sangat efektif karena metode ini melibatkan pengguna dalam proses perancangannya, sehingga pembuatan prototype dan pengujian bisa dilakukan dengan cepat dan estimasi waktu yang diperlukan hanya 5 hari. Sehingga peneliti menggunakan metode Design Sprint untuk mendesain fitur yang ditambahkan yaitu mencari lokasi rapat dengan memanfaatkan teknologi Location Based Services.

\subsection{Rumusan Masalah}

Rumusan masalah pada penerapan location based service untuk pencarian lokasi rapat menggunakan metode design sprint ini adalah sebagai berikut:

1. Bagaimana cara menerapkan metode design sprint dalam fitur pencarian lokasi rapat di Sistem Informasi dan Manajemen Rapat di Institut Teknologi Nasional Malang ?

2. Bagaimana cara memanfaatkan teknologi location based service yang ada diperangkat smart phone saat ini?

\subsection{Batasan Masalah}

Dalam penyusunan skripsi agar menjadi sistematis dan mudah dimengerti, maka akan diterapkan beberapa batasan masalah, antara lain :

1. Data yang digunakan merupakan data kuesioner yang didapatkan dari.hasil observasi dan wawancara pada bagian kepegawaian di ITN Malang.

2. Data merupakan set data yang berjumlah 20 record dengan detail parameter data dosen, data karyawan dan data kebutuhan pengguna yang didapatkan dalam bentuk format excel. 
3. Ini hanya akan diujikan pada aplikasi Sistem Informasi dan Manajemen Rapat Institut Teknologi Nasional Malang.

4. Data yang diolah pada aplikasi ini hanya terbatas pada data gedung yang ada pada Institut Teknologi Nasional Malang.

5. Metode yang digunakan untuk mendesain fitur pencarian lokasi rapat adalah metode pengembangan software Design Sprint.

\subsection{Tujuan}

Adapun yang menjadi tujuan penulisan penelitian skripsi ini adalah sebagai berikut :

1. Mengetahui apakah pengembangan Sistem Informasi dan Manajemen Rapat dengan menambahkan fitur pencarian lokasi rapat ini akan membantu dan mempermudah pengguna.

2. Dengan adanya sistem yang dikembangkan diharapkan dapat membantu pengguna menghemat waktu dalam mencari lokasi rapat sehingga rapat dapat berjalan dengan efektif.

\section{TINJAUAN PUSTAKA}

\subsection{Penelitian Terdahulu}

Menurut Prasetyo pada penelitiannya yang berjudul "Perancangan Aplikasi Bimbingan Skripsi Berbasis Mobile dengan menggunakan Pendekatan Design Sprint", dimana penelitian ini bertujuan untuk merancang suatu aplikasi dengan pendekatan design sprint yang merupakan kerangka kerja untuk melakukan validasi ide awal, membuat hipotesa lalu menguji ide tersebut dengan sebuah prototype. Pada penelitian terdapat 3 tahap untuk melakukan design sprint, yaitu studi pustaka, design sprint planning dan design sprint phases \& methods. Hasil dan kesimpulan dari penelitian ini adalah dengan melakukan pendekatan design sprint mencegah kegagalan dalam perancangan aplikasi ditahap implementasi atau pengembangan dan dapat membuat prototype yang mudah digunakan. [4]

Menurut Rokhmawati pada penelitiannya yang berjudul "Perancangan User Interface Aplikasi EzyPay menggunakan Metode Design Sprint", peneliti menggunakan metode ini karena proses perancangan dan pembuatan prototype yang singkat dan cepat. Alasan mengapa peneliti menggunakan metode ini adalah urgensi waktu dari pihak EzyPay sehingga metode ini cocok digunakan disituasi tersebut. Design sprint merupakan metodologi desain yang dikembangkan oleh google untuk menyelesaikan masalah dengan melibatkan pengguna melalui melalui perancangan, pembuatan protoype, dan pengujian ide dengan cepat. Pada penelitian ini terdapat lima tahapan dalam melakukan design sprint, dimana fase ini dinamakan sesuai dengan nama hari yaitu fase senin, selasa, rabu, kamis, dan jumat. Tujuan utama dari masing-masing fase adalah menentukan tujuan(senin), mencari solusi(selasa), memutuskan solusi(rabu), membuat protoype(kamis), dan melakukan validasi(jumat). Hasil dari penelitian ini didapat responden menilai aplikasi EzyPay adalah aplikasi yang bagus, mudah digunakan, dan tampilan user interface yang menarik sehingga menggunakan metode design sprint adalah solusi yang tepat. [5]

Menurut Yulianto pada penelitiannya yang berjudul "Teknologi Location Based Service (Global Positioning System) Pada Perangkat Mobile", perancangan perangkat lunak menggunakan teknologi Location Based Service (LBS) yang merupakan bagian dari teknologi komunikasi berbasiskan pada posisi lokasi geografi. Tujuan penelitian ini adalah merancang aplikasi LBS untuk diimplementasikan pada perangkat mobile dengan sistem operasi Android yang didukung oleh teknologi GPS (Global Positioning System) serta menggunakan infra struktur jaringan GPRS (General Packet Radio Service) sebagai penghubung dengan server untuk menghasilkan rute terpendek dengan menggunakan algoritma Dijkstra metode Fibonacci Heap. Metode pengembangan piranti lunak yang digunakan adalah Rational Unified Process. Hasil penelitian ini merupakan perancangan aplikasi LBS yang dapat diimplementasikan pada perangkat mobile berbasis Android. Simpulan dari penelitian menunjukkan pencarian rute terpendek dengan algoritma Dijkstra metode Fibonacci Heap sebagai algoritma single source shortest path yang lebih cepat daripada algoritma Dijkstra biasa dan Bellman Ford [1].

\subsection{Dasar Teori}

\subsubsection{Design Sprint}

Design sprint adalah sebuah metodologi yang dapat merancang dan membangun aplikasi dengan cepat dan mudah. Terdapat enam tahap dalam melakukan metode design sprint ini, yaitu :

1. Understand : pada tahap ini ditentukan apa kebutuhan pengguna dan teknologi apa yang cocok untuk diimplementasikan. Ditahap ini dilakukan observasi terhadap pengguna tentang masalah yang terjadi pada pengguna dan penting memahami apa yang dialami oleh pengguna.

2. Define : setelah melakukan tahap understand, selanjutnya menentukan solusi dari permasalahan yang dialami oleh pengguna.

3. Diverge : sebelum melaksanakan tahap decide dilakukan tahap diverge terlebih dahulu dimana pada tahap ini dikembangkan lebih dalam dari solusi yang dibuat, dan memprediksi masalah apa yang akan muncul pada solusi tersebut.

4. Decide : pada tahap ini ditentukanlah solusi yang tepat dari permasalahan yang terjadi. Penentuan solusi dipilih melalui voting atau pemungutan suara.

5. Prototype : selanjutnya membuat suatu bentuk fisik dari suatu ide atau solusi yang dipilih baik berupa catatan yang dipasang di dinding, objek, atau storyboard.

6. Validate : pada tahap terakhir ini dilakukan uji coba kepada pengguna dari protoype yang dibuat., Pengujian ini selain ditujukan untuk 
pengguna bisa juga ditujukan untuk stakeholder atau seseorang yang ahli pada bidang tertentu.[7]

\subsubsection{Location Based Services}

Location Based Services (LBS) atau layanan berbasis lokasi adalah istilah umum yang digunakan untuk menggambarkan teknologi yang digunakan untuk menemukan lokasi perangkat yang kita gunakan. Dua unsur utama LBS adalah:

1. Location Manager (API Maps)

Menyediakan tools/source untuk LBS, Application Programming Interface (API) Maps menyediakan fasilitas untuk menampilkan, memanipulasi maps/peta beserta feature-feature lainnya seperti tampilan satelit, street (jalan), maupun gabungannya. Paket ini berada pada com.google.android.maps

2. Location Providers (API Location)

Menyediakan teknologi pencarian lokasi yang digunakan oleh device/perangkat. API Location berhubungan dengan data GPS (Global Positioning System) dan data lokasi real-time. API Location berapa pada paket android yaitu dalam paket android.location. Dengan Location Manager, kita dapat menentukan lokasi kita saat ini, Track gerakan/perpindahan, serta kedekatan dengan lokasi tertentu dengan mendeteksi perpindahan [3]

\section{METODE PENELITIAN}

\subsection{Pengembangan Sistem SeMar}

Dalam merancang pengembangan sistem, peneliti menggunakan metode design sprint sebagai metodologi perancangannya. Dalam.metode ini terdapat enam tahap yaitu understand, define, diverge, decide, prototype, dan validate. Peneliti akan menjelaskan apa saja yang akan dilakukan pada tahap ini.

\subsubsection{Understand}

Berdasarkan permasalahan utama yang terdapat pada Sistem Informasi Manajemen Rapat Institut Teknologi Nasional Malang adalah belum adanya fitur untuk mencari lokasi rapat. Sehingga pegawai atau dosen yang masih baru bekerja kurang begitu mengenal lingkungan di Institut Teknologi Nasional Malang. Peneliti akan melakukan wawancara dengan pegawai dan dosen di ITN Malang.

\subsubsection{Define}

Setelah peneliti menemukan masalah yang terjadi pada pegawai dan dosen, peneliti menentukan sebuah solusi untuk menyelesaikan masalah ini. Peneliti akan mulai mengumpulkan hasil wawancara dari pegawai dan dosen ITN Malang, lalu mengidentifikasi kebutuhan pengguna jika fitur pencarian lokasi rapat ini akan dikembangkan di platform mobile. Kebutuhan pegawai dan dosen akan disusun secara sistematis dan terstruktur.

\subsubsection{Diverge}

Ketika sebuah solusi sudah ditentukan, akan dibuat desain pra-antarmuka yang masih bersifat low-fidelty. Desain antarmuka yang dibuat akan ditinjau oleh dosen yang berpengalaman dibidangnya. Selain itu peneliti juga akan membuat storyboard untuk skenario pengalaman pengguna dalam menggunakan sistem yang sudah dikembangkan.

\subsubsection{Decide}

Setelah membuat desain pra-antarmuka dan melakukan peninjauan ulang dengan dosen yang terkait, peneliti akan menetapkan desain antarmuka mana yang cocok dan sesuai dengan kebutuhan pengguna.

\subsubsection{Prototype}

Setelah melaksanakan tahap deciding, peneliti akan mulai membangun pengembangan prototype sistem berdasarkan desain dan storyboard yang dibuat. Pembuatan prototype dimulai dari desain yang bersifat high-fidelity sehingga pengguna akan lebih mudah memahami bagaimana alur dan cara kerja sistem yang dikembangkan.

\subsubsection{Validate}

Setelah selesai membuat prototype dari sistem yang dikembangkan, peneliti akan mulai menguji hasil dari prototype ke calon pengguna yaitu pegawai dan dosen ITN Malang. Hasil dari tahap validate ini adalah bagaimana reaksi pengguna dalam memakai fitur atau sistem yang dikembangkan. Apakah fitur atau sistem yang dikembangkan mempermudah pengguna atau tidak.

\subsection{Blok Diagram Sistem}

Kuat sinyal yang dipancarkan oleh satelit akan diterima oleh unit antena dan selanjutnya diteruskan pada unit penerima GPS pada frekuensi tertentu, dari sinyal yang diterima pada rangkain penerima GPS yang masih berbentuk kode-kode sinyal dihitung dan diubah menjadi sinyal digital oleh kalkulator android yang diproses oleh mikrokontroler dan diteruskan pada rangkaian interface aplikasi untuk digunakan sebagai sarana komunikasi dengan perangkat mobile smart phone.

Sistem akan mengambil data lokasi dari web server lalu selanjutnya akan dilakukan proses untuk menentukan titik koordinat pada lokasi tersebut sehingga sistem akan merepresentasikan hasilnya melalui interface sistem.

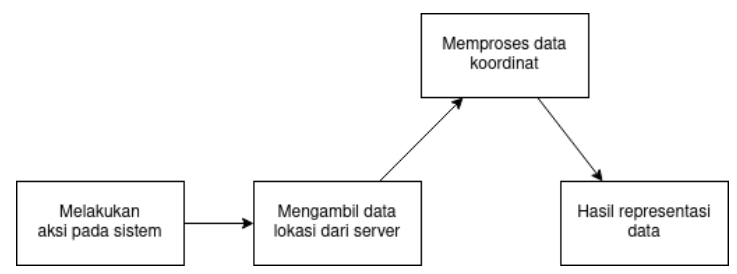

Gambar 3.2 Blok diagram Location Based Services 


\subsection{Flowchart Sistem}

Flowchart sistem ini menjelaskan proses berjalananya aplikasi seperti ditunjukkan pada Gambar 3 .

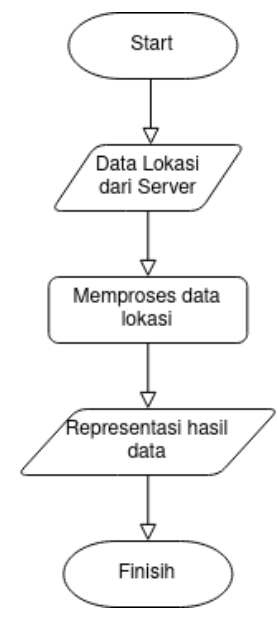

\section{Gambar 3.3 Flowchart Sistem Location Based} Services

Berdasarkan flowchart pada Gambar 3.3, sistem dimulai dengan ketika pengguna menekan tombol untuk mencari lokasi. Selanjutnya sistem mengambil data lokasi dari server. Lalu sistem memproses data lokasi dari server, dan terakhir sistem akan memrepresentasikan hasil data berupa tampilan peta.

\section{HASIL DAN PEMBAHASAN}

\subsection{Implementasi Design Sprint}

Implementasi merupakan tahapan penelitian yang dilakukan setelah perancangan dan analisis. Pada tahapan ini, akan dibuat sebuah aplikasi sesuai dengan rancangan yang sebelumnya telah dipaparkan. Pengembangan aplikasi akan mengikuti desain present solution sketch sebelumnya, begitu juga dengan penerapan teknologi location based services didalam sistem akan mengikuti desain dan rancangan dari design sprint.

\subsubsection{How Might We}

Pada tahap how might we adalah dimana peneliti mencari peluang untuk pengembangan aplikasi SeMar ini. Hasil dari tahap ini mempermudah karyawan atau dosen baru dalam mencari lokasi rapat sehingga rapat dapat berjalan secara efisien.

\subsubsection{User Interviews}

Melakukan user interviews kepada pemilik aplikasi SeMar dengan memberi pertanyaan mengenai kekurangan apa yang ada aplikasi ini. Kesimpulan dari hasil interview ini adalah belum ada fitur untuk mencari lokasi rapat.

\subsubsection{Present Solution Sketch}

Membuat sketsa untuk tampilan antarmuka aplikasi yang nanti akan dikembangkan. Berikut hasil present solution sketch.

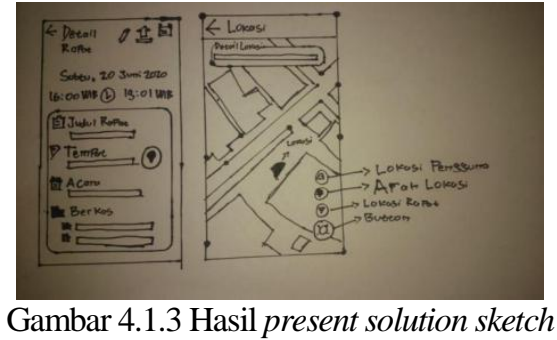

\subsubsection{Prototyping Real Enough}

Tahap ini menjelaskan prototipe dari fitur yang dirancang berdasarkan dari hasil sketch prototyping pada tahap design sprint. Berikut tampilan prototype dari pencarian lokasi rapat. Gambar pada halaman detail rapat akan tombol disamping kanan tempat rapat. Ketika tombol tersebut ditekan akan menuju halaman lokasi rapat. Pada halaman lokasi rapat akan terdapat 3 floating action button dipojok kanan bawah tampilan.

Tombol pertama akan menunjukkan lokasi pengguna saat ini, lalu tombol kedua akan menampilkan petunjuk arah antara pengguna dengan lokasi rapat, dan tombol terakhir akan menunjukkan lokasi rapat.
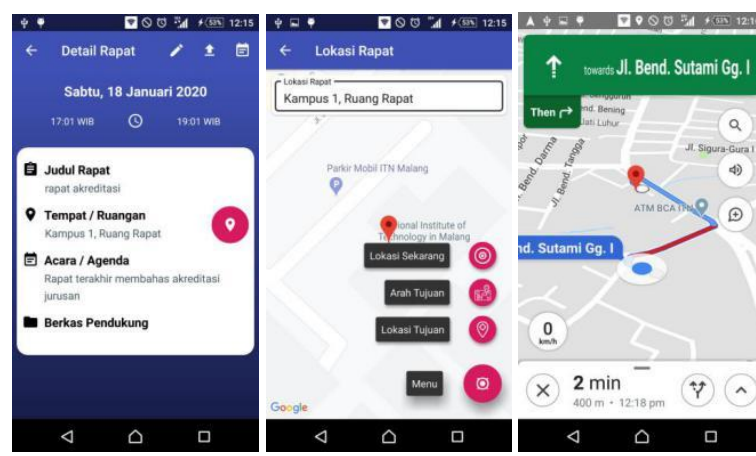

Gambar 4.1.4 Prototype fitur pencarian lokasi rapat

\subsubsection{Usability Study}

Pada tahap ini dilakukan pendataan kuesioner kepada dosen dan karyawan dengan prototype pencarian lokasi rapat yang dibuat. Terdapat pertanyaan yang sama kepada pengguna dosen yaitu:

1. Bagaimana antarmuka fitur lokasi pencarian rapat ini?

2. Apakah fitur ini memudahkan anda dalam mencari lokasi rapat?

3. Apakah yang harus dikembangkan lagi pada aplikasi SeMar ini?

\section{Tabel 4.1 Hasil Kuesioner Dosen}

\begin{tabular}{|c|c|}
\hline $\begin{array}{l}\text { Partisipan } \\
\text { Kuesioner }\end{array}$ & Kesimpulan Kuesioner \\
\hline Dosen 1 & $\begin{array}{l}\text { Tampilan yang cukup menarik, sangat } \\
\text { membantu untuk mencari jalur tercepat } \\
\text { ke lokasi rapat. Kedepannya } \\
\text { ditambahkan absensi rapat dengan fitur } \\
\text { face recognition, kelola user profile, } \\
\text { penjadwalan rapat dengan metode } \\
\text { tertentu. }\end{array}$ \\
\hline Dosen 2 & Tampilan antarmuka yang bagus, \\
\hline
\end{tabular}




\begin{tabular}{|c|c|}
\hline & $\begin{array}{l}\text { mempermudah dalam mencari lokasi } \\
\text { rapat. }\end{array}$ \\
\hline Dosen 3 & $\begin{array}{l}\text { Tampilan yang sederhana tapi } \\
\text { menarik, dan sangat membantu dalam } \\
\text { proses pencarian lokasi rapat. }\end{array}$ \\
\hline Dosen 4 & $\begin{array}{l}\text { Antarmuka yang bagus, cukup } \\
\text { membantu dalam pencarian lokasi } \\
\text { rapat akan tetapi ruang rapat di ITN } \\
\text { Malang tidak banyak sehingga fitur ini } \\
\text { kurang membawa dampak yang cukup } \\
\text { besar untuk penggunanya. }\end{array}$ \\
\hline Dosen 5 & $\begin{array}{l}\text { Tampilan antarmuka yang bagus, akan } \\
\text { tetapi kurangnya paduan untuk } \\
\text { pemakaian SeMar ini sehingga } \\
\text { pengguna membutuhkan waktu untuk } \\
\text { bisa memakai aplikasi SeMar. } \\
\text { Diharapkan ada video singkat } \\
\text { pemakaian SeMar di playstore. }\end{array}$ \\
\hline Dosen 6 & $\begin{array}{l}\text { Tampilan antarmuka yang biasa, } \\
\text { dan belum bisa memberikan } \\
\text { pendapat karena belum dapat } \\
\text { mencoba fitur secara langsung. } \\
\text { Untuk pengembangan selanjutnya } \\
\text { diperlukan menu untuk } \\
\text { menambahkan lokasi baru. }\end{array}$ \\
\hline Dosen 6 & $\begin{array}{l}\text { Tampilan antarmuka yang biasa, } \\
\text { dan belum bisa memberikan } \\
\text { pendapat karena belum dapat } \\
\text { mencoba fitur secara langsung. } \\
\text { Untuk pengembangan selanjutnya } \\
\text { diperlukan menu untuk } \\
\text { menambahkan lokasi baru. }\end{array}$ \\
\hline Dosen 7 & $\begin{array}{l}\text { Desain antarmuka yang biasa, dan } \\
\text { sangat membantu untuk dosen baru. } \\
\text { Untuk pengembangan selanjutnya } \\
\text { ditambahkan fitur live streaming } \\
\text { rapat. }\end{array}$ \\
\hline Karyawan1 & $\begin{array}{l}\text { Tampilan antarmuka yang cukup } \\
\text { menarik, dan cukup membantu } \\
\text { untuk kelancaran pelaksanaan } \\
\text { rapat. }\end{array}$ \\
\hline Karyawan 2 & $\begin{array}{l}\text { Tampilan antarmuka yang bagus, } \\
\text { sangat memudahkan untuk menuju } \\
\text { lokasi rapat. }\end{array}$ \\
\hline
\end{tabular}

\subsubsection{Sprint Conclusion: Recap and Next Steps}

Berdasarkan hasil kuesioner pada tahap usability 7 dosen dan 2 karyawan telah mengisi dan memberi masukan yang membangun. Hasil dari kuesioner didapat bahwa pengembangan dari aplikasi SEMAR dengan menambahkan fitur pencarian lokasi rapat cukup membantu sebagian besar pengguna, sehingga tahap implementasi kepada programmer dapat dilakukan.

\subsection{Pengujian Location Based Services}

Pada pengujian location based services peneliti menggunakan Google Maps Api untuk menerapkan fitur lokasi pencarian rapat. Terdapat keterbatasan penggunaan pada Google Maps Api dikarenakan pengubahan kebijakan yang dilakukan oleh google.

Tabel 4.2 Pengujian Location Based Services

\begin{tabular}{|l|l|}
\hline \multicolumn{1}{|c|}{$\begin{array}{c}\text { Fitur Location Based } \\
\text { Services }\end{array}$} & \multicolumn{1}{|c|}{ Fungsional } \\
\hline $\begin{array}{l}\text { Lokasi pengguna saat ini } \\
\text { Arah tujuan dari pengguna ke }\end{array}$ & $\begin{array}{l}\text { Berjalan dengan baik } \\
\text { Tidak berjalan dengan } \\
\text { baik }\end{array}$ \\
\hline Lokasi rapat & Berjalan dengan baik \\
\hline
\end{tabular}

\section{KESIMPULAN DAN SARAN}

\subsection{Kesimpulan}

Berdasarkan beberapa pengujian yang telah dilakukan didapatkan kesimpulan :

1. 1ada tahap pengujian usability study dimana 9 calon pengguna telah mengisi dan memberi masukan untuk pengembangan sistem kedepannya. Didapat bahwa pengembangan dari aplikasi SEMAR dengan menambahkan fitur pencarian lokasi rapat cukup membantu sebagian besar pengguna, sehingga tahap implementasi kepada programmer dapat dilakukan.

2. Penggunaan location based service Google Maps API memiliki keterbatasan pada fitur tertentu. Sehingga fitur lokasi pencarian rapat ini tidak dapat berjalan optimal.

3. Pengujian pada beberapa perangkat menunjukkan bahwa semua fitur yang dirancang dapat berjalan dengan baik, kecuali untuk fitur arah lokasi karena pengguna harus memiliki aplikasi google map bawaan agar dapat menggunakan fitur ini.

\subsection{Saran}

Berdasarkan penelitian yang telah dilakukan, maka penulis dapat memberikan saran-saran untuk pengembangan selanjutnya antar lain :

1. Selain pendekatan Design Sprint yang dikemukan oleh google, penelitian ini dapat dikembangkan menggunakan metode perancangan seperti Scrum, dan Agile Development.

2. Terdapat alternatif penggunaan Location Based Services yang open source, yaitu OpenLayers, Mapbox, HERE, dan Mapfit.

\section{DAFTAR PUSTAKA}

[1] Yulianto, B. (2010). Teknologi Location Based Service (Global Positioning System) pada Perangkat Mobile. Jurnal ComTech, 1(1), 61-74.

[2] Rofiq, M., \& Uzzy, R. F. (2014). Penentuan Jalur Terpendek Menuju Cafe Di Kota Malang Menggunakan Metode Bellman-Ford dengan Location Based Service Berbasis Android. Jurnal Ilmiah Teknologi dan Informasi ASIA Vol, 8(2).

[3] Rompas, B. R., Sinsuw, A. A., Sompie, S. R., \& Lumenta, A. S. (2012). Aplikasi Location-based Service Pencarian Tempat di Kota Manado Berbasis Android. E-journal Teknik Elektro dan Komputer, 1(2). 
[4] Prasetyo, A., Az-Zhara, H. M., \& Brata, H. Adam (2019). Perancangan Aplikasi Bimbingan Skripsi Berbasis Mobile dengan menggunakan Pendekatan Design Sprint. Jurnal Pengembangan Teknologi Informasi dan Ilmu Komputer, 3(6), 5808-5816.

[5] Rokhmawati, R. I., Az-Zhara, H. M., \& Ramadhana, R., (2019). Perancangan User Interface Aplikasi EzyPay menggunakan Metode Design Sprint. Jurnal Pengembangan Teknologi Informasi dan Ilmu Komputer, 3(9), 8831-8840.
[6] Subagaya, K. A., Pratami, D., \& Hasibuan, M. A., (2019). Pengembangankonten E-Learning Menggunakan Design Sprint Pada Mata Kuliah Manajemen Proyek. Jurnal Integrasi Sistem Industri, 6(2).

[7] Sumual, H., Batmetan, J. R., \& Kambey, M. (2019). Design Sprint Methods for Developing Mobile Learning Application. 3rd UNJ International Conference on Technical and Vocational Education and Training 2018, KnE Social Science, 394- 407. 